\title{
Advances of Carbon Capture and Storage in Coal-Based Power Generating Units in an Indian Context
}

\author{
Anoop Kumar Shukla ${ }^{1}{ }^{\circ}$, Zoheb Ahmad ${ }^{1}$, Meeta Sharma ${ }^{1}$, Gaurav Dwivedi ${ }^{2}{ }^{\circ}$, \\ Tikendra Nath Verma ${ }^{3}$, Siddharth Jain ${ }^{4}\left(\mathbb{D}\right.$, Puneet Verma ${ }^{5, *}$ and Ali Zare ${ }^{6}$ \\ 1 Department of Mechanical Engineering, Amity University Uttar Pradesh, Noida 201301, India; \\ shukla.anoophbti@gmail.com (A.K.S.); ahmadzohaib12003@gmail.com (Z.A.); msharma15@amity.edu (M.S.) \\ 2 Energy Centre, Maulana Azad National Institute of Technology, Bhopal 462003, India; gdiitr2005@gmail.com \\ 3 Department of Mechanical Engineering, Maulana Azad National Institute of Technology, Bhopal 462003, \\ India; verma.tikks@gmail.com \\ 4 Department of Mechanical Engineering, College of Engineering Roorkee, Roorkee 247667, India; \\ arthjain2001@gmail.com \\ 5 School of Chemistry, Physics and Mechanical Engineering, Queensland University of Technology, \\ Brisbane 4001, Australia \\ 6 Flow, Aerosols \& Thermal Energy (FATE) Group, School of Engineering, Deakin University, Victoria 3216, \\ Australia; ali.zare@deakin.edu.au \\ * Correspondence: puneet.verma@qut.edu.au
}

Received: 21 June 2020; Accepted: 5 August 2020; Published: 10 August 2020

\begin{abstract}
India is a nation with a diverse economy that requires tremendous resources to completely meet the desires of its compatriots in various sectors. In terms of energy resources and requirements, coal-based power plants can fulfill the bulk of these electricity needs. India is very reliant on coal, which is used in power plants as a primary energy source. However, the usage of coal energy at a higher level continuously pollutes the atmosphere. The Indian power market alone accounts for half of the country's $\mathrm{CO}_{2}$ emissions, which implies that significant action is needed to contain environmental pollution. Carbon Capture and Storage (CCS) is a bridging technique and feasible alternative for the carbon fired plant processing of $\mathrm{CO}_{2}$. However, the application of CCS in coal-fired power stations is still uncommon in the nation. At the UNFCCC Paris Summit, India committed to reduce its carbon emission intensity by approximately $30-33 \%$ by 2030 . In this work, several CCS systems, possible $\mathrm{CO}_{2}$ origins, and emission levels in India are discussed. Various advanced methods for $\mathrm{CO}_{2}$ capture and separation are also highlighted. Furthermore, the current work discusses CCS situations and the applications of CCS in India along with its manifold challenges.
\end{abstract}

Keywords: carbon capture and storage; Green House Gas; coal fired power plant; fertilizer

\section{Introduction}

Carbon capture and storage (CCS) is the procedure through which $\mathrm{CO}_{2}$ is extracted from different large-scale firms in the industrial sector, after which these unused $\mathrm{CO}_{2}$ emissions are seized and deposited far below the ground, which leads to a reduction in the emissions of greenhouse gas (GHG) emissions. CCS is a workable choice for the removal of 50-85\% of GHG emissions by the year 2050 [1]. Without a CCS infrastructure, it will be extremely difficult to keep up with the environmental alterations in the forthcoming years [2].

India is a growing economy that is quickly transitioning from villages to metropolitan areas. Therefore, India's energy demands and carbon pollution are projected to change rapidly [2,3]. India's 
economy is forecasted to expand by $7.4 \%$ in 2018 , requiring more electricity to fulfill this demand. An expected 308.80 billion tonnes of coal is reserved and used as the primary energy source for the majority of India's budget [4], and India ranks number five in terms of global power production. Coal-fired power stations play a significant role in this type of production and contribute to the largescale carbon pollution of greenhouse gases. Another main cause of $\mathrm{CO}_{2}$ pollution is cement production. In 2017, India generated approximately 195 GW power from coal fire power plants, which was roughly $60 \%$ of the total production of $330 \mathrm{GW}$ [5].

The primary GHG responsible for global warming and alterations in environmental patterns is $\mathrm{CO}_{2}$ [4]. GHGs absorb the heat radiated heat by the Earth's surface due to their complex molecular structure; this phenomenon increases the temperature of the environment. Figure 1 provides a measure of the $\mathrm{CO}_{2}$ emissions per capita of different nations. In 2018, the Earth's total $\mathrm{CO}_{2}$ content increased from 300 to $410 \mathrm{ppm}$, which further added to the rising oceanic levels due to global warming [5]. In 1992, India participated for the United Nations Climate Change Framework Convention (UNFCCC, for instance) and welcomed an offer to negotiate in the Kyoto Protocol in 2002. However, the government did not take the rising GHG pollution seriously [5].

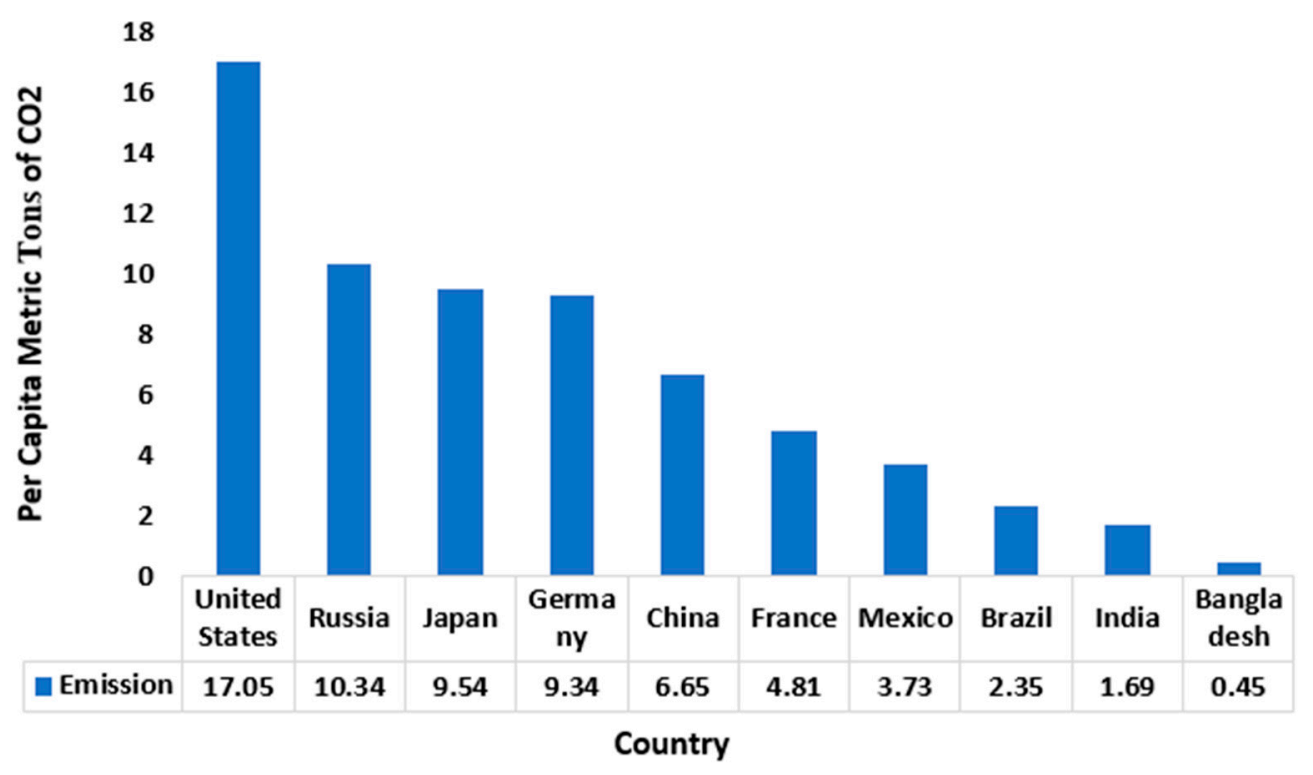

Figure 1. Comparison of emissions of $\mathrm{CO}_{2}$ per capita in different nations [6].

According to a 2007 report, India has become the sixth largest GHG emitter in the world, and by the year 2030, it is likely to be the second-largest emitter in the world [7]. India is currently the third most polluted nation worldwide in terms of $\mathrm{CO}_{2}$ emissions, followed by China and the USA. The country is thus facing climatic issues and their effect on the production of energy, agriculture, and human social resources. A report by Parikh and Ghosh [8] anticipated that an increase in the climatic temperature by $0.5{ }^{\circ} \mathrm{C}$ will occur in India by 2030. This is an alarming situation, and the government needs to develop suitable policies to reduce GHG emissions.

The primary purpose of this research is to highlight the working performance of CCS arrangements, along with the challenges that emerge during its implementation across the nation. This paper also discusses the possible routes of $\mathrm{CO}_{2}$ emissions and the technological routes for $\mathrm{CO}_{2}$ capture that cover all the three major components: post-combustion, pre-combustion, and oxy-fuel combustion. Various separation methods of $\mathrm{CO}_{2}$ are also explored in this study, along with different means of transporting and storing $\mathrm{CO}_{2}$. Finally, the status of CCS technology in an Indian context is highlighted. All the outcomes and consequences of this research are entirely concerned to an Indian perspective. 


\section{Possible Carbon Roots and Emission Conditions}

\subsection{Coal}

Coal is a vital local fossil fuel in India, which is considered the foremost coal manufacturer followed by China and United States. The share of coal for profitable energy stock in India was 54\% [7]. The coal-based electricity generation potential was 125 GW in 2012 and estimated to be 330-441 GW by 2050. Table 1 shows the power generation capacity of different nations during 2015 to 2050. It can be seen that the power generation capability of India and other Asian nations is increasing significantly. Table 2 shows the world-wide usage of energy by the year 2050. Coal will play a crucial role in fulfilling the increasing energy usage in India. The heating performance of indigenous coal is lower than that of externally exchanged coal by a usual amount of around $4000 \mathrm{kcal} / \mathrm{kg}$. Such findings explicitly demonstrate that coal cannot be ignored in the immediate term in possible $\mathrm{CO}_{2}$ streams. Table 3 displays the installed capacity of different types of power plants in India as of the year 2016 in specific sectors. Here, coal contributes the primary portion among all other available fuel options. Figure 2 presents the growth of coal demand, showing a steady annual increase in coal production across the global market. It is expected that the emissions of nations that are not independently evaluated will follow a business-as-usual (BAU) pathway. Figure 3 shows the production of fossil fuel in tonnes of oil equivalent (TOE) among different countries. The domestic carbon supply is projected to increase by 2035 , owing to the growing demand for energy in million tonnes of oil equivalent (MTOE), as shown in Figure 4.

Table 1. World-wide generation of electricity [9].

\begin{tabular}{ccc}
\hline Nations & Power Production by 2015 (TWh) & Power Production by 2050 (TWh) \\
\hline India & 1383 & 5663 \\
China & 5844 & 10,763 \\
European Union & 3204 & 3935 \\
United States & 4297 & 5414 \\
Other Asian nations & 868 & 3220 \\
Central East along with North Africa & 1450 & 3009 \\
\hline
\end{tabular}

Table 2. World-wide consumption of primary energy by the year 2050 [9].

\begin{tabular}{cc}
\hline Nations & Energy Consumed by 2050 (Mt), Approx. \\
\hline India & 2544 \\
China & 4022 \\
Other Asian nation & 1544 \\
Latin America & 1021 \\
Non-OECD * nations & 2038 \\
Sub-Saharan Africa & 1246 \\
Central East along with North Africa & 1679 \\
International bunkers & 661 \\
\hline
\end{tabular}

* OECD means Organization for Economic Co-operation and Development.

Table 3. Sector-specific installed capacity in megawatts for different plants in India by the year 2016 [10].

\begin{tabular}{|c|c|c|c|c|c|c|c|c|}
\hline Sectors & Hydro & & Thermal & & Overall & Nuclear & Renewable & Overall \\
\hline States & 28.092 & $\begin{array}{c}\text { Coals } \\
64.320 .50\end{array}$ & $\begin{array}{l}\text { Gases } \\
697530\end{array}$ & $\begin{array}{c}\text { Petro-diesel } \\
438,57\end{array}$ & 7173437 & nil & 1934.22 & 101760.59 \\
\hline Central & 1571.42 & 51,390 & 7555.33 & nil & $58,945.33$ & 5780 & nil & $76,296.75$ \\
\hline Private & 3120 & $69,462.38$ & 9978 & 554.96 & $79,995.34$ & nil & $36,887.29$ & $120,002.63$ \\
\hline All India & $42,783.42$ & $185,172.88$ & $24,508.63$ & 993.53 & $210,675.04$ & 5780 & $38,821.51$ & $298,059.97$ \\
\hline
\end{tabular}




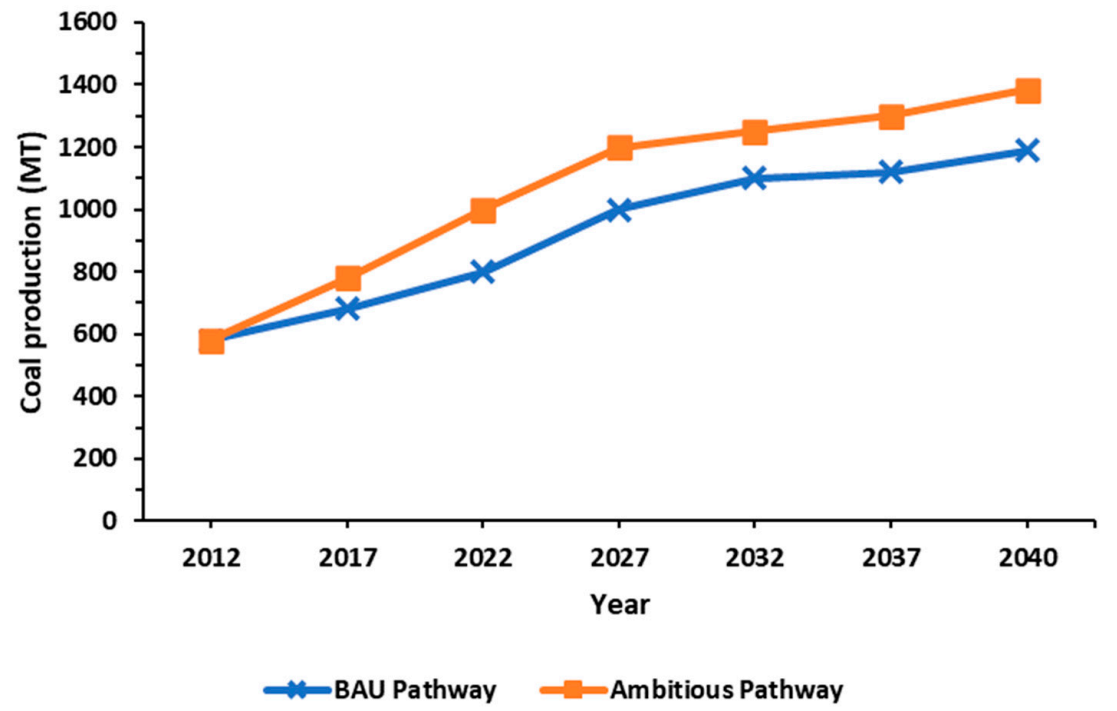

Figure 2. Global growth in the demand of coal in an ambitious pathway and business-as-usual (BAU) pathway.

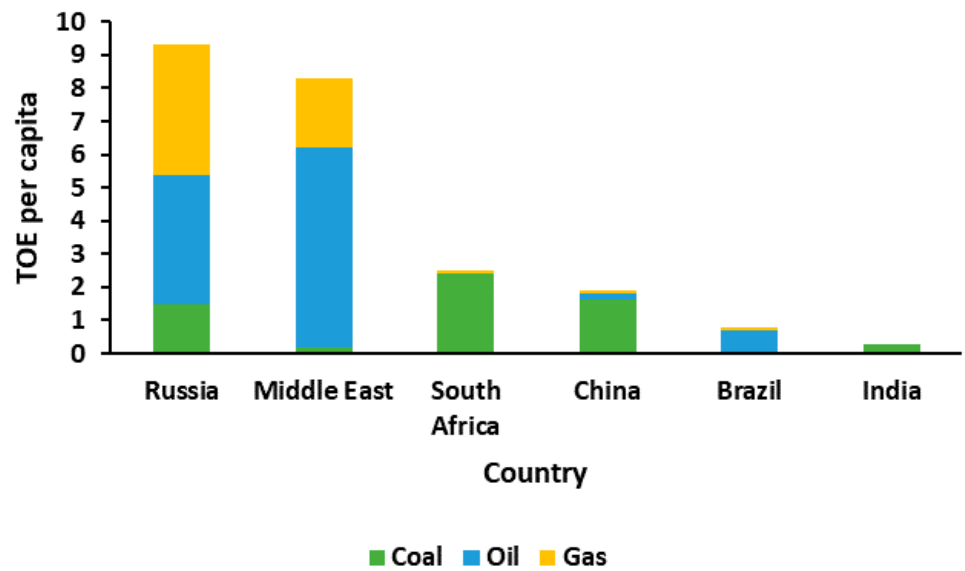

Figure 3. Production of fossil fuel in different nations along with India [11].

\section{Globally coal demand growth}

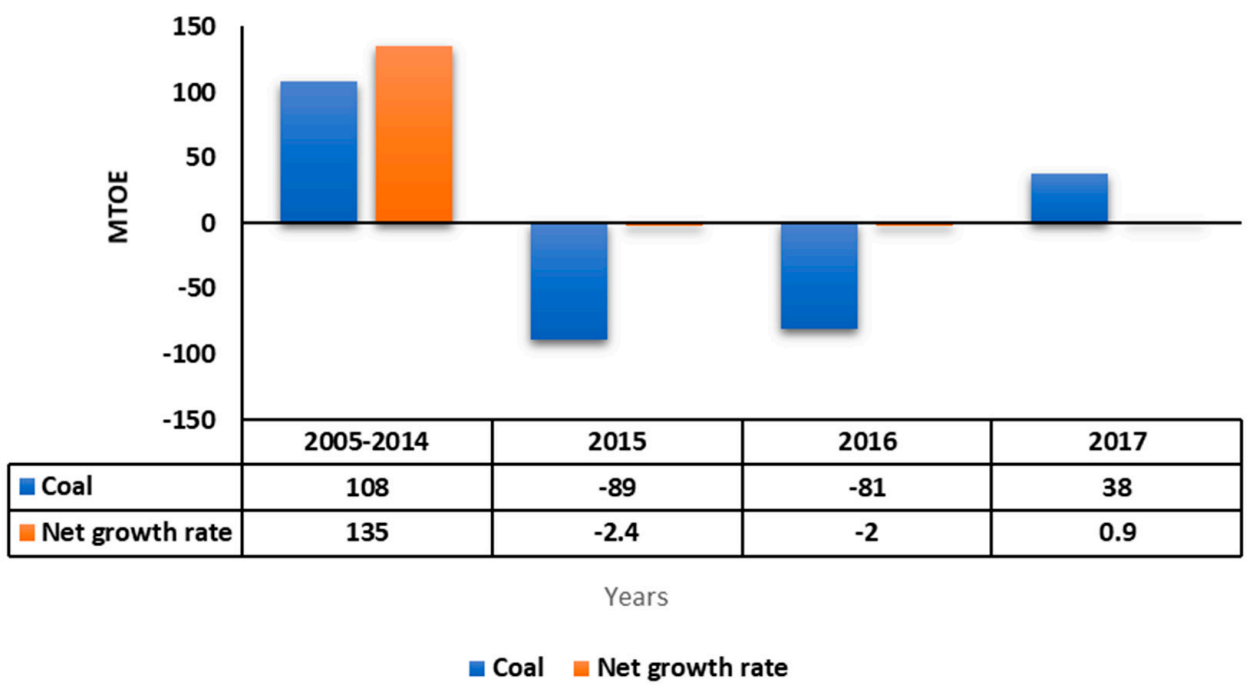

Figure 4. Trends for the production of domestic coal in India [12]. 


\subsection{Thermal Power Plants}

In India, most thermal power plants use coal as their primary sources of energy. The rate of $\mathrm{CO}_{2}$ emissions from such power stations is continuously rising, as shown in Table 4. These emissions are expected to reach approximately 3700 million tonnes by 2035 [13].

Table 4. Emissions of $\mathrm{CO}_{2}$ (million tonnes) for the power sector in India from 2011-2012 to 2015-2016 [10].

\begin{tabular}{cccccc}
\hline Year & 2011-2012 & 2012-2013 & 2013-2014 & 2014-2015 & 2015-2016 \\
\hline $\mathrm{CO}_{2}$ & 637.8 & 696.5 & 727.4 & 805.4 & 846.3 \\
\hline
\end{tabular}

\subsection{Fertilizer Plants}

In India, agriculture is the primary occupation, and Indian farmers utilize a large amount of fertilizer in their farming. Fertilizer production units are the primary source of $\mathrm{CO}_{2}$ emissions. Two main forms of fertilizers-phosphatic and nitrogenic-are produced effectively in 56 broad fertilizer units. Fertilizer plants emit a significant proportion of $\mathrm{CO}_{2}$ emissions, which are mostly produced by ammonia factories. However, sometimes this amount of $\mathrm{CO}_{2}$ is inadequate for plants that produce urea. Hence, additional $\mathrm{CO}_{2}$ generation units are added to fertilizer plants. Approximately 18 ammonia processing plants produce more than 0.1 million tonnes of $\mathrm{CO}_{2}$ pollution a year with a $\mathrm{CO}_{2}$ emission rate of $2104 \mathrm{~kg}$ per tonne of ammonia [14].

\subsection{Cement Plant}

Over the past 20 years, worldwide cement consumption has increased by 30\% [15]. In India, cement factories have raised their share in overall $\mathrm{CO}_{2}$ discharges from $3.3 \%$ to $4.8 \%$, while the world level is about 4\% [16]. Such facilities are now pursuing acceptable CCS technology.

\subsection{Refineries}

There are 23 refineries in the Indian oil market. The domestic sale of petroleum products in India for the year 2015-2016 is shown in Table 5 [3]. During this time, the overall volume was $231.92 \mathrm{Mt}$. The projected annual emissions of $\mathrm{CO}_{2}$ from major point sources alone was $721 \mathrm{Mt}$, which was roughly half of India's overall emissions [5]. Figure 5 presents the $\mathrm{CO}_{2}$ emissions from Indian petroleum during 2010-2016. In India, there are many facilities used in the fields of defence, farming, and space stations that constantly emit $\mathrm{CO}_{2}$ into the atmosphere. India is the third-largest source of electricity in the world. The share of power generation capacity between the federal, state, and private sectors in India during 2006-2014 is presented in Figure 6.

Table 5. Allocation of fossil fuel production in India during 2015-2016 [4].

\begin{tabular}{cc}
\hline Supply & Allotment (\%) \\
\hline Diesel & 42.5 \\
Gasoline & 15.24 \\
Naphtha & 7.71 \\
Air mechanism fuel & 5.07 \\
Petroleum coke & 5.73 \\
Fuel & 4.21 \\
Lubricant-oil & 0.46 \\
Soft diesel & 0.18 \\
Bitumen & 2.23 \\
Condense petroleum gases & 4.57 \\
Kerosene oil & 3.22 \\
Other & 8.9 \\
\hline
\end{tabular}




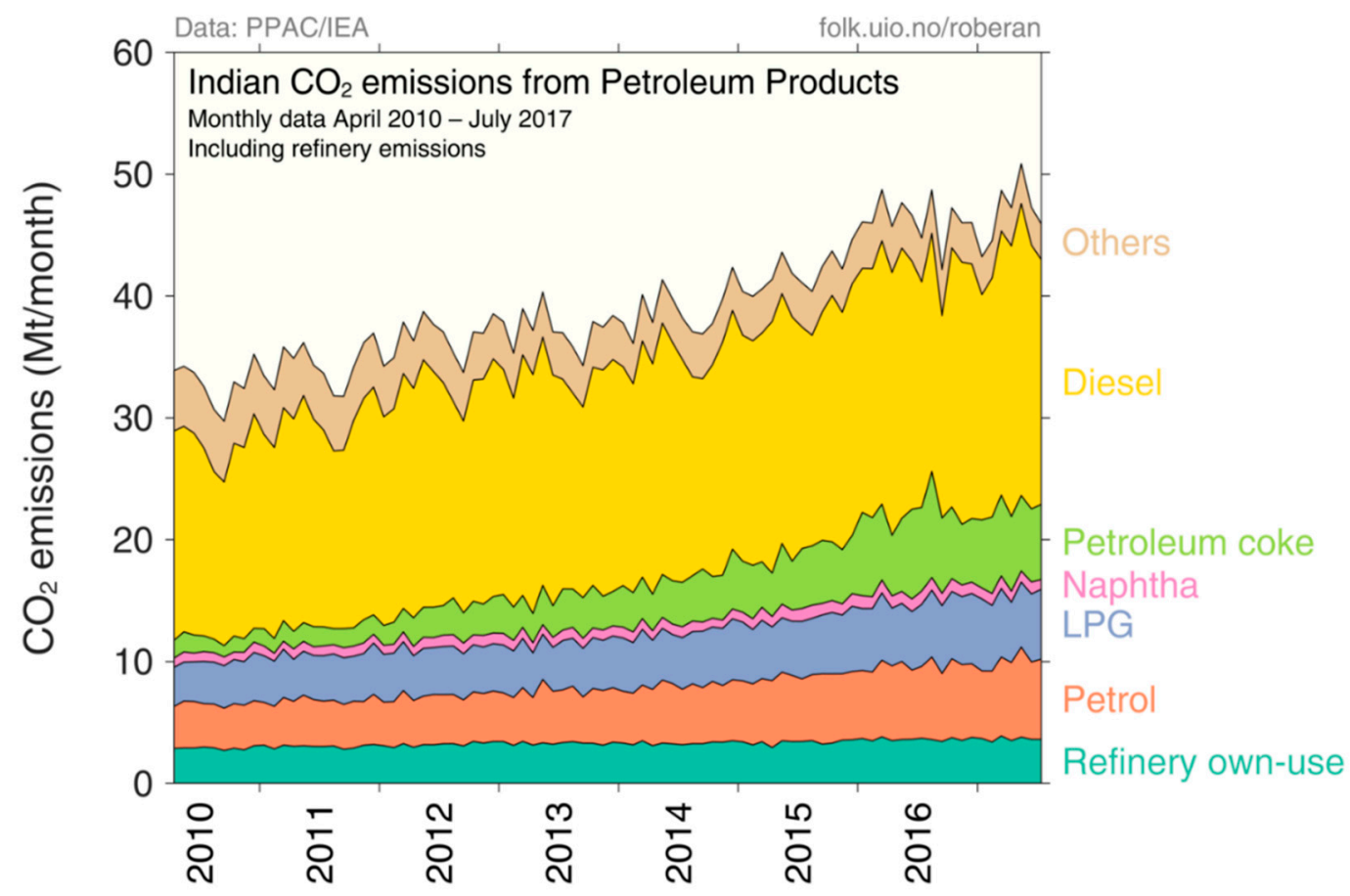

Figure 5. $\mathrm{CO}_{2}$ emissions by Indian petroleum 2010-2016 [17].

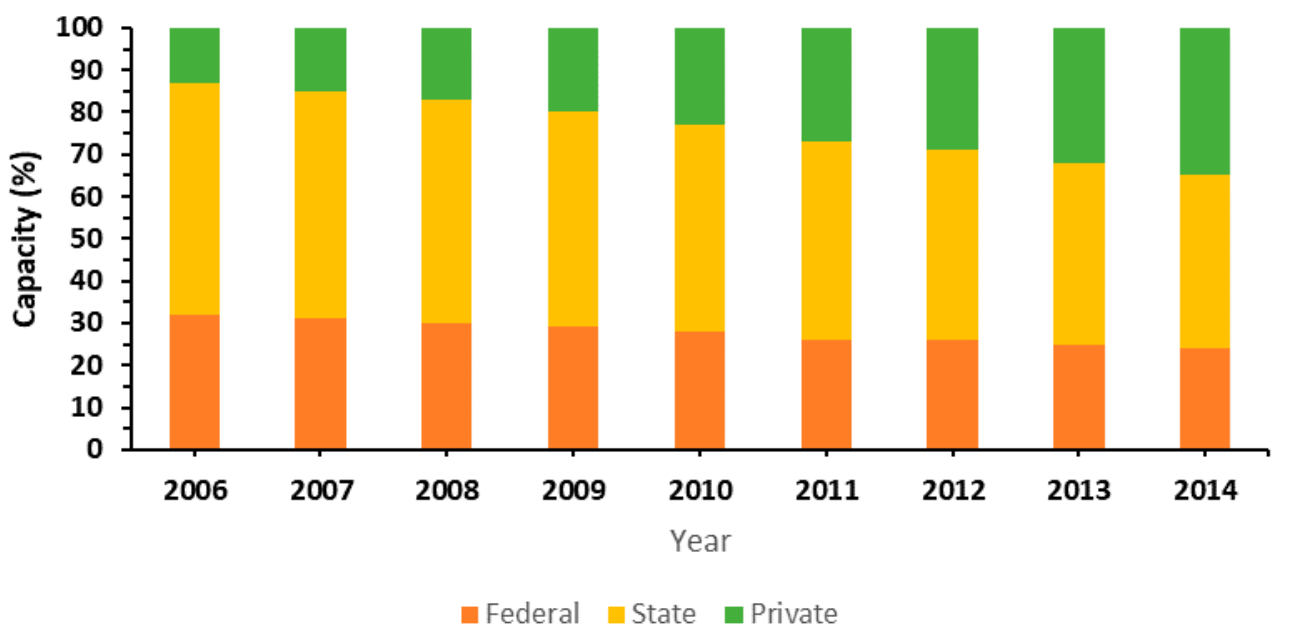

Figure 6. Capacity of power generation by ownership in India [11].

\section{Technological Routes for $\mathrm{CO}_{2}$ Capture}

The productive capture of anthropogenic $\mathrm{CO}_{2}$ discharged on a large scale, such as from large industrial plants, is viewed as a significant system to reduce the amount of $\mathrm{CO}_{2}$ gases in the atmosphere. This is because the age of $\mathrm{CO}_{2}$ is vital in the burning of hydrocarbon energies, which is a day by day event among India's coal-fired thermal power plants [2]. At present, there are three technological routes used to capture $\mathrm{CO}_{2}$ content: pre-combustion, post-combustion, and oxyfuel combustion. Figure 7 shows a detail explanation of each process.

\subsection{Pre-Combustion Capture}

Pre-combustion capture entails the removal of carbon dioxide gases from fossil fuels before the completion of the combustion process. In pre-combustion capture, fossil fuel-based power-plants are partially oxidized in steam and oxygen under high pressure and temperature to form syngas [18]. This gas combination consists of $\mathrm{H}_{2}, \mathrm{CO}, \mathrm{CO}_{2}$, and small amounts of other gases $\left(\mathrm{CH}_{4}\right)$. The syngas 
reacts further through the water-gas shift to change $\mathrm{CO}$ and $\mathrm{H}_{2} \mathrm{O}$ into $\mathrm{H}_{2}$ and $\mathrm{CO}_{2}$, thereby producing a high concentration mixture of $\mathrm{H}_{2}$ and $\mathrm{CO}_{2}$. The amount of $\mathrm{CO}_{2}$ in this mix can lie between 20 and $45 \%$. The $\mathrm{CO}_{2}$ is then able to be trapped and isolated from the gas mixture $[19,20]$.

This pre-combustion strategy brings about significant expenses for mixed solvent recovery. However, this drawback is obviated by using a physical solvent. The costs are lower for physical solvents, which are recovered through pressure reduction. These solvents are also preferred for usage in high pressure and lower temperature regions as they are suitable for industrial plants with higher $\mathrm{CO}_{2}$ concentrations [21].

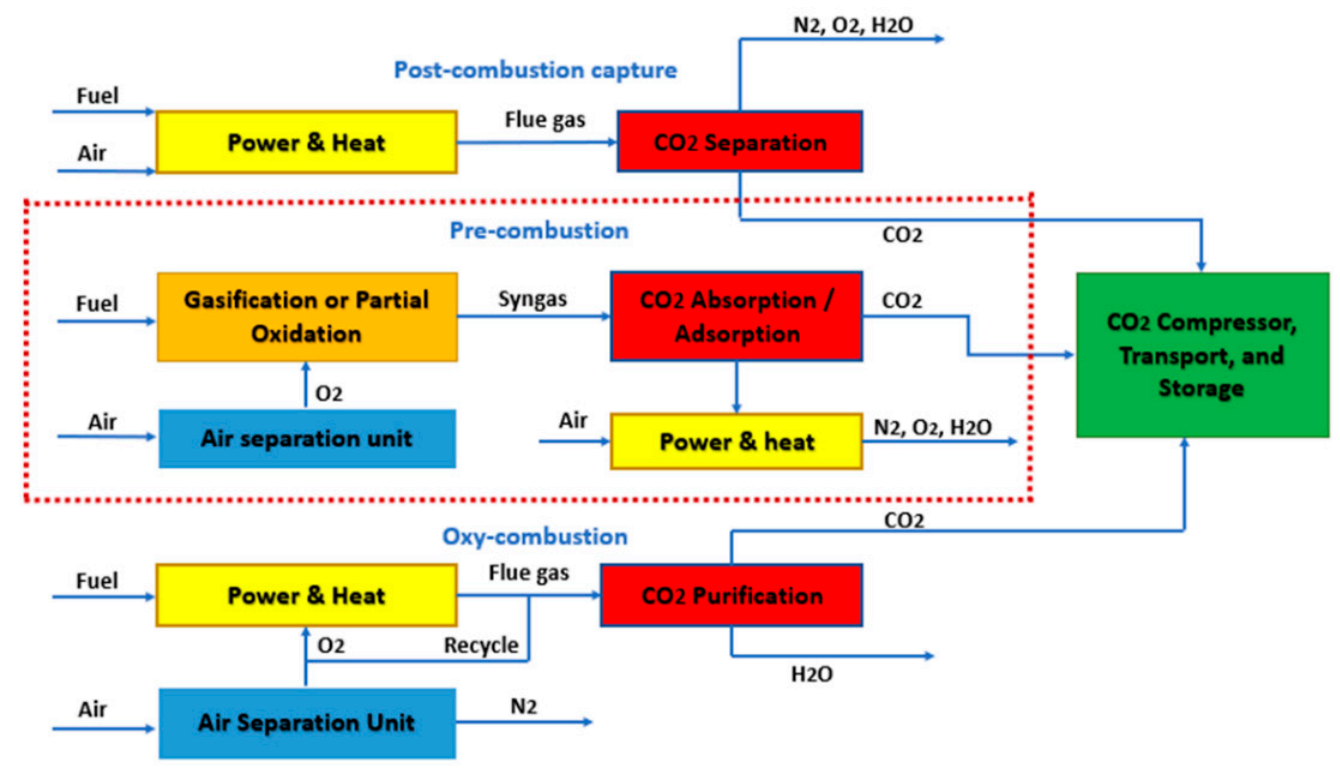

Figure 7. Schematics of $\mathrm{CO}_{2}$ capture technologies for power plants [22].

\subsection{Post-Combustion Capture}

The primary objective of this $\mathrm{CO}_{2}$ capture technology is to isolate and seize the $\mathrm{CO}_{2}$ available in the gases that are produced from the ignition of fossil fuels. This technique is able to seize carbon gas from power-plants and is, therefore, sometimes called post-conversion capture. However, once this technique is functional in power-plants, it is considered post-combustion $\mathrm{CO}_{2}$ capture. The post-combustion strategy for $\mathrm{CO}_{2}$ capture incorporates solvent absorption, cryogenic separation, membrane partitioning, and stable sorbent adsorption. Post-combustion capture is considered a fully developed $\mathrm{CO}_{2}$ capture methodology due to its effective and superior adaptability for fossil fuel-based power plants.

\subsection{Oxy-Fuel Combustion}

Oxy-fuel combustion is considered the best method for seizing $\mathrm{CO}_{2}$ in power-plants with the help of a CCS mechanism. This process generally entails the ignition of fuels that consist of clean oxygen gas rather than air. The primary reason for utilizing such a method for biofuels and plants is to produce high amounts of $\mathrm{CO}_{2}$ and hydraulic vapor in the atmosphere that can easily be seized or separated through a low-temperature dehydration process. Clean oxygen is delivered by cryogenics, which include consuming and flaming coal in pure oxygen. The key benefit of oxy-fuel CCS is that the vent air remains accessible under a massive $\mathrm{CO}_{2}$ accumulation of roughly $75.69 \mathrm{~mol} \%$, allowing a reduction in the compression rate and encouraging effective $\mathrm{CO}_{2}$ evacuation.

\section{4. $\mathrm{CO}_{2}$ Separation Techniques}

Innovative routes for $\mathrm{CO}_{2}$ capture alone cannot work correctly until there are ways to boost the process of capturing pure $\mathrm{CO}_{2}$ more efficiently [23]. Now and in the future, a broad scope of 
carbon capture and separation methods by vapor streams remains necessary to actualize India's coal-fired thermal plants. This also depends on the relevant physical and compound procedures, which incorporate adsorption, cryogenic absorption, and membrane separation technology. Figure 8 shows all the $\mathrm{CO}_{2}$ separation procedures currently utilized. The following sections describe the details of these methodologies.

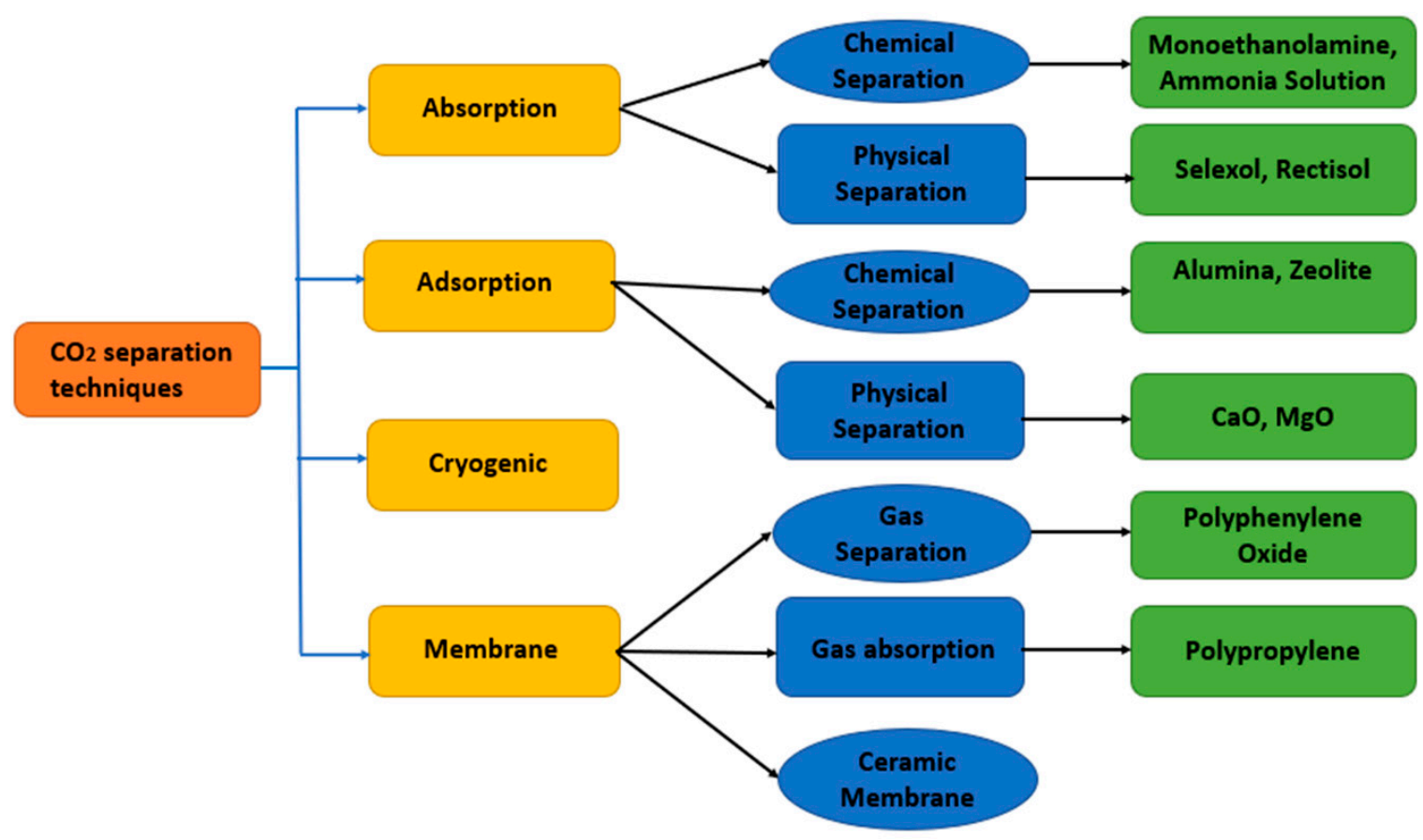

Figure 8. Different technologies for $\mathrm{CO}_{2}$ separation [24].

\subsection{Absorption}

The standard absorption method includes the utilization of compound solvents to catch $\mathrm{CO}_{2}$ from flue gases. For the separation of $\mathrm{CO}_{2}$ from complex gases, most methods utilize solvents, such as amines and cold methanol, alongside an ammonia mixture (solvent) [25]. Even though this technique is considered a fully developed technology for $\mathrm{CO}_{2}$ capture, the use of solvents in this method makes it corrosive to nature and energy exhaustive during the solvent regeneration process. A significant constraint of this procedure is that it utilizes fluid sponges, which erode the funneling in power plants. Thus, this method is not entirely appropriate for use in India's coal-fired thermal plants. The solvents utilized for $\mathrm{CO}_{2}$ retention are separated into their chemical parts and physical parts. The physical parts utilize natural solvents to genuinely assimilate corrosive gas segments (as opposed to responding artificially), whereas chemical retention relies upon the corrosive base balance responses utilizing soluble solvents [26,27].

\subsubsection{Chemical Absorption Solvents}

There are many chemical-based solvents that are used for the separation of unwanted gases like $\mathrm{CO}_{2}$ and $\mathrm{H}_{2} \mathrm{~S}$ from the mainstream air. $\mathrm{CO}_{2}$ is retained by utilizing amines to shape a dissolvable carbonate salt. Some of the most common amine-built solvents utilized in an organic course are conventional amine-based solvents and sterically hindered amine solvents. Presently, amine-based solvents are considered a element that could be potentially applied to lessen $\mathrm{CO}_{2}$ emissions in mechanical procedures, such as those used in petroleum derivative power plants, concrete creation, and steel fabrication [28]. 


\subsubsection{Physical Absorption of Solvents}

A physical process is commonly prescribed to isolate $\mathrm{CO}_{2}$ in the pre-burning phase, which ordinarily works at elevated $\mathrm{CO}_{2}$ pressure. Physical solvents can specifically catch $\mathrm{CO}_{2}$ without chemical reactions through interactions with gas. These physical solvents are non-corrosive in nature and are easy to operate, as there are no chemical reactions between the solvents. However, this process is considered very expensive, as the cost of solvents is very high. Some common processes that use physical solvents are Selexol ${ }^{\mathrm{TM}}$, Rectisol ${ }^{\mathrm{TM}}$, and Fluor ${ }^{\mathrm{TM}}$ [28].

\subsection{Adsorption}

This method is widely utilized in organic (chemical process) and natural procedures (environment). Some of the different adsorbents used are zeolites, enacted carbons, polyaspart-amide, oxides of metal, permeable silicate, natural structures of metal and chitosan for the carbon seizing process $[29,30]$. Capturing carbon via innovative adsorption processes with the help of activated carbon fiber is considered an effective approach [31]. This method is gaining widespread consideration because of its qualities, which combine the least amount of required energy, simple support, straightforward activities, and adaptability. Adsorption-based division procedures are classified as pressure swing adsorption (PSA) and temperature swing adsorption (TSA). In adsorption-built gas purification procedures, PSA is regularly favored over TSA because of the simplicity of its activities and its unwavering quality. TSA forms have not ordinarily been utilized for mechanical gas detachment because of the low-warmth conductivity of the adsorbent bed, which causes trouble in desorbing polluting influences and recovering the adsorbent [32]. However, in hotter regions, temperature swing adsorption is a valuable method since it is modest and utilizes less energy. Accordingly, this method can lessen working expenses if it is fused into coal-terminated plants [28,33]. Regardless, this process also involves extended cooling along with warming occasions for carbon capture.

\subsubsection{Temperature Swing Adsorption (TSA)}

Temperature swing adsorption is considered an alluring technology for the expulsion of $\mathrm{CO}_{2}$ from various types of mainstream gases. In TSA applications, the sifter will adsorb a larger measure of contaminants when the strainer bed temperature is lower. Hence, a gas or fluid stream is taken into the sifter bed at a low temperature for a period of time to adsorb a contaminant onto the strainer and expel it from the stream. The strainer bed is then warmed, normally by using a hot, clean stream (a pure gas) to recover the sifter for reuse. Next, the bed is chilled so the adsorption procedure can start from the beginning once more.

TSA applications consider the best utilization of the strainer limit because high temperature recovery is the best at expelling adsorbed contaminants. These applications are also the best for expelling contaminants from the inlet stream. TSA with sub-atomic strainers are qualified for the evacuation of contaminants in specific applications. As a rule, TSA is required for the expulsion of impurities from $\mathrm{CO}_{2}$ and $\mathrm{H}_{2} \mathrm{O}$. TSA is utilized in natural gas dehydration plants and cryogenic oxygen plants [30,34].

\subsubsection{Pressure Swing Adsorption (PSA)}

Pressure swing adsorption is a technology used to isolate a few gas varieties from a blend of gases under different amounts of pressure. In PSA applications, a strainer is utilized to increase the sifter limit by employing a higher pressure [35]. In this kind of use, the defiled feed stream is taken into the strainer beds under a high weight for a time; then, the sifter bed pressure is diminished to recover the sifter and expel the adsorbed impurities. Although this strategy is not as practical for recovering the strainer, a vacuum can be added to the recovery procedure to additionally decrease the pressure [21,36]. This procedure is called vacuum pressure swing adsorption (VPSA) and is utilized in large-scale oxygen plants. 
There are several benefits to pressure swing adsorption over temperature swing adsorption. In PSA, the main advantage is protecting the sieve from high temperatures, which avoids the degradation of the feed stream compounds. Otherwise, these broken compounds can stick to the sieve and reduce its efficiency [31].

\subsection{Membrane Separation}

Corti et al. [37] observed that separating $\mathrm{CO}_{2}$ with the help of membranes is only applicable when the amount of $\mathrm{CO}_{2}$ in gases is greater than $\sim 10 \%$. The innovative membrane separation process works according to differences in $\mathrm{CO}_{2}$ properties, where $\mathrm{CO}_{2}$ with chemical interactions is trapped, and other $\mathrm{CO}_{2}$ with physical interactions is allowed to pass through the membranes. These membrane units are likewise utilized as gas ingestion segments or regular layer partition units. Even though film technology is novel, it needs considerable energy for separation and is broadly recognized to have poor selectivity. This represents a significant impediment for $\mathrm{CO}_{2}$ capture utilizing films. This technique also utilizes either an inorganic ceramic membrane or natural polymeric layers [38]. Clay layers are very costly, and it is very challenging to accomplish a high degree of $\mathrm{CO}_{2}$ separation, as well as high purity at the same time, from flue gas across a single stage clay or polymeric layer. These are also significant impediments to $\mathrm{CO}_{2}$ capture technology.

\subsection{Cryogenic Separation}

Cryogenic separation involves the separation of $\mathrm{CO}_{2}$ from gas that consists of a large percentage of carbon (more than $50 \%$ ). The cryogenic partition strategy for $\mathrm{CO}_{2}$ seizure is founded on the rule of compression and cooling [39]. This strategy is generally functional in $\mathrm{CO}_{2}$ capture contexts where the gases comprise a substantial concentration of $\mathrm{CO}_{2}$. The cryogenic partition cannot be utilized in $\mathrm{CO}_{2}$ seizure through power-plants because these plants have a progressively weakened $\mathrm{CO}_{2}$ stream. Another problem is that this technology needs an excessive amount of energy for $\mathrm{CO}_{2}$ separation. In most cryogenic separation methodologies, different segments of vapour blends are isolated with the progression of pressure, and refrigeration [40]. Pollutants decrease the temperature needed for carbon vapour in cryogenic detachment procedures to around $80^{\circ} \mathrm{C}$. In this situation, the refrigeration energy penalty increases significantly, and there is an significant chance of $\mathrm{CO}_{2}$ ice development, which poses a risk to apparatus protection.

\section{5. $\mathrm{CO}_{2}$ Transport}

When the $\mathrm{CO}_{2}$ is caught and packed, it is then moved to capacity depots. The transport of $\mathrm{CO}_{2}$ is not very difficult because $\mathrm{CO}_{2}$ can easily be transported over long distances through pipelines. Boats are also considered possible methods for long-distance $\mathrm{CO}_{2}$ transport. Utilizing existing oil pipelines is the most practical transportation alternative for separations up to $1000 \mathrm{~km}$. The transportation of $\mathrm{CO}_{2}$ under extended separations is similar to transporting condensed gaseous petrol. Without oil pipeline systems, new high-weight pipelines specially implemented for $\mathrm{CO}_{2}$ transport would be much costlier.

\section{Challenges of $\mathrm{CO}_{2}$ Carriage Through Pipe Ducts}

The carriage of $\mathrm{CO}_{2}$ by means of a pipeline faces some specialized and monetary difficulties that emerge from the low-profile pipeline configuration. A great deal of $\mathrm{CO}_{2}$ can be effectively moved through a pipeline if the $\mathrm{CO}_{2}$ is in the dense phase [41]. $\mathrm{CO}_{2}$ in the dense phase is especially sensitive to the presence of steep heights and contamination. This not only affects the pressurised separation in the pipeline framework but also influences the liquid elements and thermodynamic conduct of the $\mathrm{CO}_{2}$ stream, yielding various stream systems that adjust the pipeline's working conditions. Specific inspection is essentially required to obtain an ideal pipeline that works correctly to continue the separation of $\mathrm{CO}_{2}$. The general development costs of $\mathrm{CO}_{2}$ pipelines are high enough that money saving advantages are being investigated. The high cost of $\mathrm{CO}_{2}$ pipeline framework developments and execution makes it important to build a structure for the financial assessment of 
carbon capture and transport chains for all tasks and working expenses [42]. This structure would have the option to evaluate the expenses of various small-scale pipelines, single large-scale pipelines, and pipelines with expanding limits. Moreover, understanding and focusing on consumption issues under low $\mathrm{pH}$ and the impact of consumption inhibitors on safeguarding the pipeline's functionality and lifespan are significant for yearly working expenses. Ultimately, $\mathrm{CO}_{2}$ transport through pipelines is assessed to evaluate theoverall annual costs which include the fixed working, and maintenance costs. The challenges with $\mathrm{CO}_{2}$ transport through pipelines are mainly focused on particular issues, such as recognition of risks, price assessment using economical model and design of structural parts of pipeline [43].

\section{6. $\mathrm{CO}_{2}$ Storage}

For environmental storage, $\mathrm{CO}_{2}$ is infused underground in an assortment of topographical conditions in muddy bowls. Within these bowls, oil and gas basins and empty fields, un-mineable coal seams, and saline patterns are potential areas of interest. Other potential stockpiling destinations for the sequestration of $\mathrm{CO}_{2}$ include integrated sinkholes, basalt rocks, and natural shales. These types of land arrangements are present both on land and seaward in different areas around the globe. However, to properly relieve the harmful natural impacts on the climate from $\mathrm{CO}_{2}$ accumulation, this capacity must be persistent. A storage chamber with long-lasting quality means that the $\mathrm{CO}_{2}$ it contains will not spill over into the climate at a large rate for many decades (usually hundreds to thousands of years). To accomplish this goal, the infusion of $\mathrm{CO}_{2}$ must occur at a depth of more than $800 \mathrm{~m}$ such that the top topographical stone can prevent the gas from relocating back to the surface. The infusion of $\mathrm{CO}_{2} \mathrm{can}$, therefore, be ended by utilizing the foundations and experience of the oil industry. The advancement of $\mathrm{CO}_{2}$ storage is occurring steadily in India [5].

The stockpiling of $\mathrm{CO}_{2}$ plays a significant role in the CCS chain and is classified into two separate groups: the collection using geological- and sea-based infrastructure. Geological infrastructure covers coal reserves, oilfields, gas fields, groundwater production, and sedimentary and freshwater resources. A large stable $\mathrm{CO}_{2}$ sink in India could be used in the Deccan volcanic province. This area includes the drainage of Kutch, Deccan, and Saurashtra. However, if storage in basalt is improved, basalt may prove to be a suitable option for India. Oil and gas fields have their own specific benefits for $\mathrm{CO}_{2}$ storage because trapped gas is incapable of escaping for a longer duration [5]. Coalmines are further treated as a viable location for the storage $\mathrm{CO}_{2}$ because coal consists of voids that serve to adsorb saline aquifers, also making them a viable choice for storage. These voids are composed of sedimentary rock consisting of mixed salt. In contrast, these voids are unfit for agriculture and humans. Furthermore, the capacity for stockpiling of $\mathrm{CO}_{2}$ in India is projected to be $5 \mathrm{Gt} \mathrm{CO}_{2}$ in large coal fields, petroleum, and gas fields. Table 6 shows storage possibilities for $\mathrm{CO}_{2}$ at different potential sites.

Table 6. Storage possibilities for $\mathrm{CO}_{2}$ in an Indian Context.

\begin{tabular}{cccc}
\hline \multirow{2}{*}{ Potential Site } & \multicolumn{3}{c}{ Reference } \\
\cline { 2 - 4 } & {$[14]$} & {$[44]$} & {$[45]$} \\
\hline Coal deposits & $2-3$ & $4-5$ & 0.344 \\
Gas-field & $2-3$ & $6-7$ & $2.71-3.49$ \\
Basalt & nil & 200 & Not available \\
Aquifer & $102-103$ & 360 & 107.31 \\
Oilfield & nil & $6-7$ & $1-1.1$ \\
\hline
\end{tabular}

\section{Challenges with CCS Deployment in the Nation}

CCS ventures are currently operating worldwide at a variety of commercial sizes, but the deployment of CCS is difficult and faces many barriers in India. Currently, a method for collecting $\mathrm{CO}_{2}$ at a lower rate from various processing industries is being sought. CCS, in this case, is important to developing countries such as India for viable resources, despite its higher costs and is the world's most 
beneficial technique to reduce GHG pollution [5]. Nonetheless, many factors, such as storage capacity, expenses, technological advancements, and skilled workers, are involved in the implementation of CCS [5]. For countries like India, it is often difficult to implement this technology due to political and socio-economic considerations. There are also other substantial obstacles, such as the higher overall cost of CCS and a lack of space and skilled workers in existing power-plants.

\subsection{Storage Portfolio}

For its effective usage in any area, CCS requires large-scale accessibility of topographical stockpiling limits. Table 7 shows the worldwide storage portfolio assessment. Here, India is under the theoretic supply level, with the projected supply lying in the range of 47-142 among the worldwide distribution center arrangement of eight states that have compelling capacity limits to characterize spillage and carbon quantities [46]. In this way, the topographical capacity subtleties in India are deficient.

Table 7. World-wide storage portfolio assessment [46].

\begin{tabular}{cccc}
\hline Nation & Valuation Status & Projected Supply $(\mathbf{G t ~ C O})$ & Supply Level \\
\hline Australia & Packed & $228-702$ & Efficient \\
China & Packed & 1574 & Efficient \\
Indian continent & Average & $47-142$ & Theoretical \\
Indonesia & Average & $1.4-2.0$ & Efficient \\
Japan & Packed & 146 & Efficient \\
Malaysia & Average & $28-29$ & Efficient \\
Canada & Packed & $197-671$ & Efficient \\
United States & Packed & $2367-21,200$ & Efficient \\
Norway & Packed & 83 & Efficient \\
\hline
\end{tabular}

\subsection{Political Arrangement of Social and Economic Needs}

India does not obey UNFCCC laws and regulations as a developing country [5]. The nation faces other problems, such as unemployment, hunger, and corruption. A massive task for India is to help its citizens with food, housing, and more essential goods. As can be seen in Table 8, which shows the socio-economic status of India, the rate of industrial growth is $7.1 \%$. India includes several states in different regions with various languages, as well as separate political groups. Thus, a collective intervention for the interests of the country as a whole is often complicated. The prioritization of socio-economic issues over GHG reductions contributes to the major weaknesses in CCS development adoption in the region [5].

Table 8. Indian Social and economic status [5].

\begin{tabular}{cc}
\hline Full size in $\mathrm{km}^{2}$ & $3,287,262$ \\
People as of 2018 & $1,353,601,823$ \\
Rate of growth as a percentage & $1.55 \%$ \\
Town-populations as of 2017 & $30 \%$ \\
Infant mortality as of 2016 & 34 \\
Lifespan expectation at birth as of 2017 & 68.79 \\
GDP (buying power equivalence) (dollars) & 10.3849 \\
GDP per capita (dollars) & 7782.9 \\
GDP progress percentage as of 2018 & $7.30 \%$ \\
Industrial production growth rate 2018 & $7.10 \%$ \\
Population below poverty line 2010 & $29.59 \%$ \\
Human Growth Index & $0.6120(134)$ \\
\hline
\end{tabular}

\subsection{Financial Barriers}

Another difficulty is the responsibility of $\mathrm{CO}_{2}$ capture and storage costs. Steady maintenance expenses and high carbon fees are relevant financial obstacles in this area. Increased energy prices 
though rising net power production represent a significant barrier to India's acceptability. There is also a need for the government of India to adopt an incentive-based system. Indeed, renewables are being encouraged by the Indian government to reduce the carbon footprint from fossil fuel-based power plants. Figure 9 shows the installed capacity of a grid interactive renewable energy-based power plant. The goal was also set for renewable energy capacities to exceed $170 \mathrm{GW}$, comprising approximately 10 GW biomass, 60 GW wind, and 100 GW solar power by March 2022.

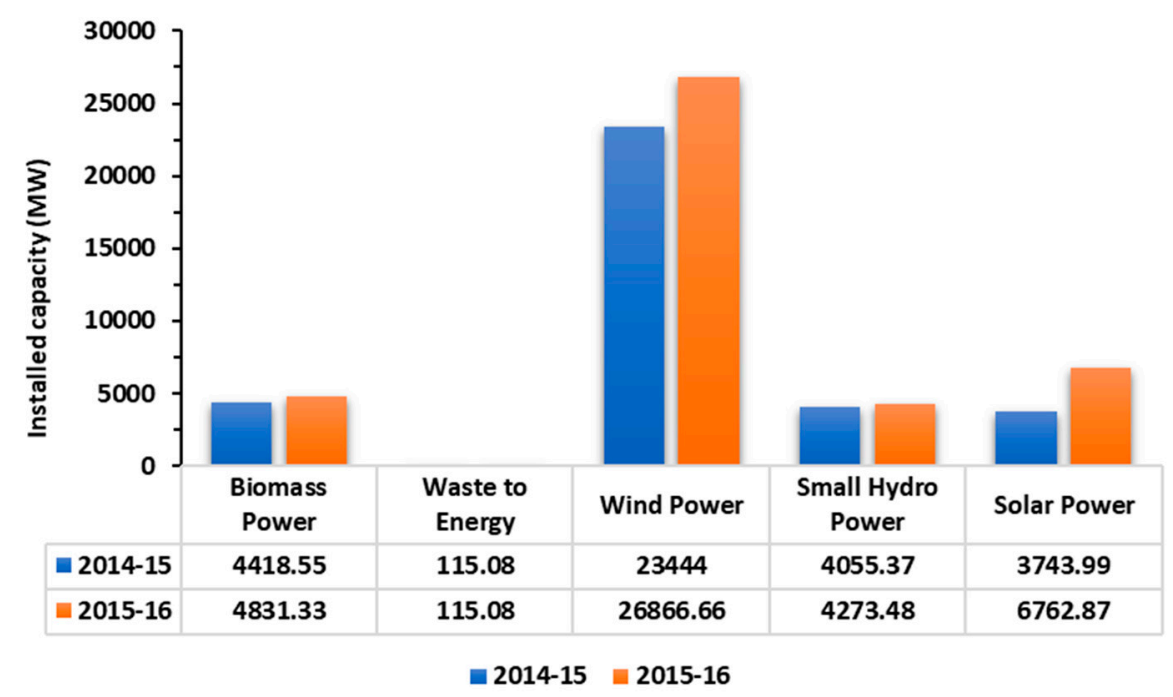

Figure 9. Data analysis of the installed capacity of the grid-interactive renewable power for 2015-2016 [4].

\subsection{Information Asymmetry}

The expenses and outputs of CCS technologies are not equally spread on the market. It is often a considerable challenge for policy leaders to have exposure to CCS project funding, as the effective price of this CCS technology is not known. [5].

\subsection{Enhanced Oil Recovery (EOR) Status}

EOR is considered to be the world's best choice for the usage of captured $\mathrm{CO}_{2}$. There are currently few oil grounds in nations like India that are satisfactorily drained for EOR. This is considered a significant problem for $\mathrm{CO}_{2}$ capturing. EOR needs support from different organizations, qualified personnel, and regulations to increase the usage capacity of carbon capture.

\section{CCS Status in India}

Industrialization is rapid in India and is very dependent on coal, which is considered a critical fuel. Thus, the nation finds it very difficult to sever its reliance on coal, which will ultimately increase the supply of global coal-based energy technology by 2040. The Indian $\mathrm{CO}_{2}$ Sequestrations Advanced Research (ICOSAR) network was established by the Department of Science and Technology (DST) to organize CCS research and development activities in 2007 [5]. Given the estimated capacity of around 220,000 MW needed for thermal energy production by 2030, many researchers [47] have sought to achieve these possible $\mathrm{CO}_{2}$ ejection estimates by broadly focusing on potential carbon gases accumulated at aggregation height in India. In India, the national thermal power corporation (NTPC) together with Bharat Heavy Electricals Limited (also known as BHEL) are making many experimental efforts to improve these factors, which is the only solution. BHEL also performed an oxyfuel check in the year 2010 at the Fuel Evaluation Test Facility (FETF).

At the beginning of 2011, many scale-up studies were planned to be carried out in a Solid Fuel Burning Test Facility (SFBTF) to build a boiler of 211/251 MW by March 2013 [47]. India's largest supplier of gas and energy (ONGC) is also exploring the usage of $\mathrm{CO}_{2}$ to improve oil retrieval or EOR at 
the Ankleshwar petroleum farm [5]. In addition to the above CCS initiatives at the domestic level, India is involved in many foreign programs and networks, such as the CSLF and the U.S. System Protocol. However, scientists concentrate primarily on the increasing expenses of introducing the CCS within carbon-fired plants. In this study, an overview of the possible opportunities for $\mathrm{CO}_{2}$ storage in India and neighboring countries was carried out. This research suggested possibilities and obstacles for introducing CCS in India to handle $\mathrm{CO}_{2}$ reduction [47]. Refer to Table 9 for further details.

Table 9. $\mathrm{CO}_{2}$ Capture and Storage-related work around India.

\begin{tabular}{|c|c|c|c|c|c|c|}
\hline Plant Category & Plant Volume & $\begin{array}{l}\text { CCS } \\
\text { Arrangement } \\
\text { Needed }\end{array}$ & $\begin{array}{l}\text { CCS Rate } \\
\text { Study }\end{array}$ & Procedure Required & Major Conclusions & Reference \\
\hline Supercritical & $660 \mathrm{MW}$ & $\begin{array}{l}\text { Post-ignition } \\
\text { along with } \\
\text { oxy-fuel } \\
\text { combustion }\end{array}$ & Yes & $\begin{array}{l}\text { Recreation by software } \\
\text { Integrated Environment } \\
\text { Control Model (IECM) }\end{array}$ & $\begin{array}{l}\text { Employment of CCS leads to } \\
\text { complex power drawbacks in the } \\
\text { growth of the power rate }\end{array}$ & [48] \\
\hline Supercritical & $500 \mathrm{MW}$ & Post-ignition & NO & $\begin{array}{l}\text { Thermal act study by } \\
\text { "CYCLE TEMPO" and } \\
\text { "ASPEN PLUS" } \\
\text { software }\end{array}$ & $\begin{array}{l}\text { A drop in plant power productivity } \\
\text { is considered as approx. } 8.3-10.8 \% \\
\text { points for high ash coal and approx. } \\
8.6-11.3 \% \text { points for small ash coal } \\
\text { associated with the matching } \\
\text { standards of base plants. }\end{array}$ & [49] \\
\hline $\begin{array}{l}\text { Supercritical } \\
\quad \text { and } \\
\text { Ultra-supercritical }\end{array}$ & $800 \mathrm{MW}$ & $\begin{array}{c}\text { Oxy } \\
\text { combustion }\end{array}$ & NO & $\begin{array}{l}\text { Thermal performance } \\
\text { study by "CYCLE } \\
\text { TEMPO" release } 5.0 \\
\text { software }\end{array}$ & $\begin{array}{l}\text { More advanced plant effectiveness } \\
\text { attained by a dual reheat structure } \\
\text { than a solo reheat structure }\end{array}$ & [50] \\
\hline
\end{tabular}

\section{Conclusions}

This review showed that by 2030, if clean coal technology is implemented, this technology will be the predominant source of energy for power plants. Carbon capture and storage are crucial solutions in this area, as the production of GHGs gradually increases.

There are significant fluctuation characteristics in the current $\mathrm{CO}_{2}$ storage capacity. Therefore, more studies are needed to implement CCS successfully in this field. We also need a long-term strategy to balance $\mathrm{CO}_{2}$ emissions. The literature argues that a low consumer price of carbon will render CCS unfeasible around the world, whereas high carbon prices will make CCS commercially viable. Overpriced carbon is expected to decline by approximately 24-35\% from 2020 to 2050, which will create hurdles for CCS implementation.

The current carbon prices for CCS implementation in India are not attractive in this sector. The development of scrubbing systems in CCS integrated power plants requires tremendous energy and thus contributes to losses in plant effectiveness. India has a tremendous capacity in its solar thermal power plants, and, in combination with this capacity, energy-intensive scrubbing can be realized. The implementation of CCS in coal-based power plants increases the cost of energy, which is not favorable for the end user. Therefore, CCS needs a maximum economic model that supports integration with coal-based power generating units to reduce GHG emissions.

This study provided a demonstrative breakdown of CCS technologies within the Indian context and analyzed the measures for the implementation of CCS in the country along with the related challenges. Various $\mathrm{CO}_{2}$ capture methods were discussed in this work, including the post-combustion capture method, which is considered the most appropriate $\mathrm{CO}_{2}$ capture method in an Indian context. The spectrum of CCS was applied and contrasted with other countries' scenarios of national coal-fired power plants. The operative planning for all abovementioned factors points towards carbon capture and storage being vital for the efficient implementation of CCS in India.

Author Contributions: A.K.S. conceived the idea, performed the data analysis, and wrote the original manuscript; Z.A. and M.S. assisted in the literature search and preparation of the figures; T.N.V., G.D., and S.J. were involved in data interpretation and revised the manuscript; P.V. and A.Z. assisted in manuscript development, supervised the project, and critically revised the manuscript. All authors have read and agreed to the published version of the manuscript.

Funding: This research received no external funding.

Conflicts of Interest: The authors declare no conflicts of interest. 


\section{References}

1. Viebahn, P.; Vallentin, D.; Höller, S. Prospects of carbon capture and storage (CCS) in India's power sector-An integrated assessment. Appl. Energy 2014, 117, 62-75. [CrossRef]

2. Boot-Handford, M.; Abanades, J.; Anthony, E.; Blunt, M.J.; Brandani, S.; Mac Dowell, N.; Fernández, J.R.; Ferrari, M.-C.; Gross, R.; Hallett, J.P.; et al. Carbon capture and storage update. Energy Environ. Sci. 2014, 7, 130-189. [CrossRef]

3. Shukla, A.K.; Sharma, A.; Sharma, M.; Nandan, G. Thermodynamic investigation of solar energy-based triple combined power cycle. Energy Sources Part A Recover. Util. Environ. Eff. 2018, 41, 1161-1179. [CrossRef]

4. Lakshmi, G.; Rathore, G.S.; Sharma, R.; Anand, A.; Sharma, S.; Hada, A.S. Energy Statistics 2017; Ministry of Statistics and Programme Implementation: New Delhi, India, 2017.

5. Kumar, R.; Jilte, R.; Nikam, K.C.; Ahmadi, M.H. Status of carbon capture and storage in India's coal fired power plants: A critical review. Environ. Technol. Innov. 2019, 13, 94-103. [CrossRef]

6. Harris, J.M.; Roach, B.; Codur, A.M. The Economics of Global Climate Change; Global Development and Environment Institute: Medford, MA, USA, 2017; p. 11.

7. Aayog, N.I.T.I. Draft National Energy Policy; National Institution for Transforming India, Government of India: New Delhi, India, 2017. Available online: http://niti.gov.in/writereaddata/files/new_initiatives/NEP-ID_27,6 (accessed on 20 May 2020).

8. Parikh, J.; Ghosh, P.P. Energy technology alternatives for India till 2030. Int. J. Energy Sect. Manag. 2009, 3, 233-250. [CrossRef]

9. Matsuo, Y.; Endo, S.; Nagatomi, Y.; Shibata, Y.; Komiyama, R.; Fujii, Y. A quantitative analysis of Japan's optimal power generation mix in 2050 and the role of $\mathrm{CO}_{2}$-free hydrogen. Energy 2018, 165, 1200-1219. [CrossRef]

10. Bhawan, S.; Puram, R.K. CO2 Baseline Database for the Indian Power Sector; Central Electricity Authority, Ministry of Power, Government on India: New Delhi, India, 2011. Available online: http://www.cea.nic.in/ reports/others/thermal/tpece/cdm_co2/user_guide_ver13.pdf (accessed on 20 May 2020).

11. Outlook, S.A.E. World Energy Outlook Special Report; International Energy Agency: Paris, France, $2015 ;$ p. 135.

12. International Energy Agency. Global Energy \& CO2 Status Report 2017; International Energy Agency: Paris, France, 2018.

13. Aydin, G. The Modeling of Coal-related $\mathrm{CO}_{2}$ Emissions and Projections into Future Planning. Energy Sources Part A Recover. Util. Environ. Eff. 2013, 36, 191-201. [CrossRef]

14. Singh, A.K.; Mendhe, V.A.; Garg, A. $\mathrm{CO}_{2}$ Storage Potential of Geologic Formations in India. In Proceedings of the 8th Greenhouse Gas Technology Conference, Trondheim, Norway, 19-22 June 2006.

15. Andrew, R.M. Global $\mathrm{CO}_{2}$ emissions from cement production. Earth Syst. Sci. Data 2018, 10, $195-217$. [CrossRef]

16. Mandal, S.K. Do undesirable output and environmental regulation matter in energy efficiency analysis? Evidence from Indian Cement Industry. Energy Policy 2010, 38, 6076-6083. [CrossRef]

17. Jackson, R.B.; Le Quéré, C.; Andrew, R.; Canadell, J.G.; Peters, G.P.; Roy, J.; Wu, L. Warning signs for stabilizing global $\mathrm{CO}_{2}$ emissions. Environ. Res. Lett. 2017, 12, 110202. [CrossRef]

18. Figueroa, J.D.; Fout, T.; Plasynski, S.; Mcllvried, H.; Srivastava, R.D. Advances in CO2 capture technology-The U.S. Department of Energy's Carbon Sequestration Program. Int. J. Greenh. Gas Control 2008, 2, 9-20. [CrossRef]

19. Michailos, S.; Emenike, O.; Ingham, D.; Hughes, K.J.; Pourkashanian, M. Methane production via syngas fermentation within the bio-CCS concept: A techno-economic assessment. Biochem. Eng. J. 2019, 150, 107290. [CrossRef]

20. Hassanpouryouzband, A.; Edlmann, K.; Yang, J.; Tohidi, B.; Chuvilin, E. $\mathrm{CO}_{2}$ Capture and Storage from Flue Gas Using Novel Gas Hydrate-Based Technologies and Their Associated Impacts. In Proceedings of the EGU General Assembly Conference Abstracts, Vienna, Austria, 3-8 May 2020; p. 20863.

21. Abbas, Z.; Mezher, T.; Abu-Zahra, M.R. Evaluation of $\mathrm{CO}_{2}$ Purification Requirements and the Selection of Processes for Impurities Deep Removal from the $\mathrm{CO}_{2}$ Product Stream. Energy Procedia 2013, 37, $2389-2396$. [CrossRef] 
22. Diaz, A.G.; Fernández, E.S.; Gibbins, J.; Lucquiaud, M. Sequential supplementary firing in natural gas combined cycle with carbon capture: A technology option for Mexico for low-carbon electricity generation and $\mathrm{CO}_{2}$ enhanced oil recovery. Int. J. Greenh. Gas Control 2016, 51, 330-345. [CrossRef]

23. Pehnt, M.; Henkel, J. Life cycle assessment of carbon dioxide capture and storage from lignite power plants. Int. J. Greenh. Gas Control 2009, 3, 49-66. [CrossRef]

24. Songolzadeh, M.; Soleimani, M.; Ravanchi, M.T.; Songolzadeh, R. Carbon Dioxide Separation from Flue Gases: A Technological Review Emphasizing Reduction in Greenhouse Gas Emissions. Sci. World J. 2014, 2014, 1-34. [CrossRef]

25. Verdon, J.P. Significance for secure $\mathrm{CO}_{2}$ storage of earthquakes induced by fluid injection. Environ. Res. Lett. 2014, 9, 064022. [CrossRef]

26. Vega, F.; Cano, M.; Camino, S.; Fernández, L.M.G.; Portillo, E.; Navarrete, B. Solvents for carbon dioxide capture. In Carbon Dioxide Chemistry, Capture and Oil Recovery; IntechOpen Limited: London, UK, 2018.

27. Zhao, Y.; Zhou, J.; Fan, L.; Chen, L.; Li, L.; Xu, Z.P.; Qian, G. Indoor $\mathrm{CO}_{2}$ Control through Mesoporous Amine-Functionalized Silica Monoliths. Ind. Eng. Chem. Res. 2019, 58, 19465-19474. [CrossRef]

28. Mondal, M.K.; Balsora, H.K.; Varshney, P. Progress and trends in $\mathrm{CO}_{2}$ capture/separation technologies: A review. Energy 2012, 46, 431-441. [CrossRef]

29. Raganati, F.; Alfe, M.; Gargiulo, V.; Chirone, R.; Ammendola, P. Kinetic study and breakthrough analysis of the hybrid physical/chemical CO2 adsorption/desorption behavior of a magnetite-based sorbent. Chem. Eng. J. 2019, 372, 526-535. [CrossRef]

30. Dhoke, C.; Cloete, S.; Krishnamurthy, S.; Seo, H.; Luz, I.; Soukri, M.; Park, Y.-K.; Blom, R.; Amini, S.; Zaabout, A. Sorbents screening for post-combustion $\mathrm{CO} 2$ capture via combined temperature and pressure swing adsorption. Chem. Eng. J. 2020, 380, 122201. [CrossRef]

31. Rubin, E.S.; Chen, C.; Rao, A.B. Cost and performance of fossil fuel power plants with $\mathrm{CO}_{2}$ capture and storage. Energy Policy 2007, 35, 4444-4454. [CrossRef]

32. Wang, M.; Lawal, A.; Stephenson, P.; Sidders, J.; Ramshaw, C. Post-combustion $\mathrm{CO}_{2}$ capture with chemical absorption: A state-of-the-art review. Chem. Eng. Res. Des. 2011, 89, 1609-1624. [CrossRef]

33. Raganati, F.; Chirone, R.; Ammendola, P. $\mathrm{CO}_{2}$ Capture by Temperature Swing Adsorption: Working Capacity As Affected by Temperature and $\mathrm{CO}_{2}$ Partial Pressure. Ind. Eng. Chem. Res. 2020, 59, 3593-3605. [CrossRef]

34. Garip, M.; Gizli, N. Ionic liquid containing amine-based silica aerogels for CO2 capture by fixed bed adsorption. J. Mol. Liq. 2020, 310, 113227. [CrossRef]

35. Nikolaidis, G.N.; Kikkinides, E.S.; Georgiadis, M.C. A model-based approach for the evaluation of new zeolite 13X-based adsorbents for the efficient post-combustion $\mathrm{CO}_{2}$ capture using P/VSA processes. Chem. Eng. Res. Des. 2018, 131, 362-374. [CrossRef]

36. Corti, A.; Lombardi, L. Reduction of carbon dioxide emissions from a SCGT/CC by ammonia solution absorption-Preliminary results. Int. J. Thermodyn. 2004, 7, 173-181.

37. Chiang, C.-L.; Lee, C.-M.; Chen, P.-C. Utilization of the cyanobacteria Anabaena sp. CH1 in biological carbon dioxide mitigation processes. Bioresour. Technol. 2011, 102, 5400-5405. [CrossRef]

38. Tan, Y.; Nookuea, W.; Li, H.; Thorin, E.; Yan, J. Property impacts on Carbon Capture and Storage (CCS) processes: A review. Energy Convers. Manag. 2016, 118, 204-222. [CrossRef]

39. Mangindaan, D.; Woon, N.M.; Shi, G.M.; Chung, T.-S. P84 polyimide membranes modified by a tripodal amine for enhanced pervaporation dehydration of acetone. Chem. Eng. Sci. 2015, 122, 14-23. [CrossRef]

40. Onyebuchi, V.; Kolios, A.; Hanak, D.P.; Biliyok, C.; Manovic, V. A systematic review of key challenges of CO2 transport via pipelines. Renew. Sustain. Energy Rev. 2018, 81, 2563-2583. [CrossRef]

41. Peletiri, S.P.; Rahmanian, N.; Mujtaba, I.M. $\mathrm{CO}_{2}$ Pipeline Design: A Review. Energies 2018, 11, 2184. [CrossRef]

42. Peletiri, S.P.; Mujtaba, I.M.; Rahmanian, N. Process simulation of impurity impacts on $\mathrm{CO}_{2}$ fluids flowing in pipelines. J. Clean. Prod. 2019, 240. [CrossRef]

43. Dooley, J.J.; Kim, S.H.; Edmonds, J.A.; Friedman, S.J.; Wise, M.A. A first-order global geological CO2-storage potential supply curve and its application in a global integrated assessment model. In Greenhouse Gas Control Technologies 7; Elsevier Science Ltd.: Amsterdam, The Netherlands, 2005; pp. 573-581. ISBN 9780080447049.

44. Holloway, S.; Garg, A.; Kapshe, M.; Deshpande, A.; Pracha, A.S.; Khan, S.R.; Mahmood, M.A.; Singh, T.N.; Kirk, K.L.; Gale, J. An Assessment of the CO2 Storage Potential of the Indian Subcontinent. Available online: http://nora.nerc.ac.uk/id/eprint/9895/1/Indian_subcontinent.pdf (accessed on 20 May 2020). 
45. Consoli, C.P.; Wildgust, N. Current Status of Global Storage Resources. Energy Procedia 2017, 114, 4623-4628. [CrossRef]

46. Garg, A.; Shukla, P.R. Coal and energy security for India: Role of carbon dioxide $\left(\mathrm{CO}_{2}\right)$ capture and storage (CCS). Energy 2009, 34, 1032-1041. [CrossRef]

47. Viebahn, P.; Höller, S.; Vallentin, D.; Liptow, H.; Villar, A. Future CCS implementation in india: A systemic and long-term analysis. Energy Procedia 2011, 4, 2708-2715. [CrossRef]

48. Akash, A.; Rao, A.; Chandel, M. Prospects of Implementing $\mathrm{CO}_{2}$ Capture and Sequestration (CCS) in the Proposed Supercritical Coal Power Plants in India. Energy Procedia 2016, 90, 604-612. [CrossRef]

49. Karmakar, S.; Kolar, A.K. Thermodynamic analysis of high-ash coal-fired power plant with carbon dioxide capture. Int. J. Energy Res. 2011, 37, 522-534. [CrossRef]

50. Suresh, M.V.J.J.; Reddy, K.; Kolar, A.K. Thermodynamic analysis of a coal-fired power plant repowered with pressurized pulverized coal combustion. Proc. Inst. Mech. Eng. Part A J. Power Energy 2011, 226, 5-16. [CrossRef]

(C) 2020 by the authors. Licensee MDPI, Basel, Switzerland. This article is an open access article distributed under the terms and conditions of the Creative Commons Attribution (CC BY) license (http://creativecommons.org/licenses/by/4.0/). 